\title{
The Animal Ethic Thoughts in the Eastern and Western Religions and Their Resource Significance
}

\author{
Zhang Yan, Fu Tongtao, Yang Weirong* \\ Department of Philosophy, School of Public Management, Nanjing Normal University, Nanjing, China \\ Email address: \\ Yangweirong121@qq.com (Yang Weirong) \\ ${ }^{*}$ Corresponding author \\ To cite this article: \\ Zhang Yan, Fu Tongtao, Yang Weirong. The Animal Ethic Thoughts in the Eastern and Western Religions and Their Resource Significance. \\ International Journal of Philosophy. Vol. 8, No. 2, 2020, pp. 38-42. doi: 10.11648/j.ijp.20200802.12
}

Received: January 11, 2020; Accepted: May 9, 2020; Published: May 28, 2020

\begin{abstract}
From the perspective of religion, philosophy and science, the animal world is a part of nature, and interacts with the human world to jointly shape the natural world and create the present state of human world outlook. However, the animal ethics in eastern and Western religions have different positions and contents because of their different ideological origins and values. The Abrahamic religions all embody a kind of religious humanitarianism in the relationship between man and animal. Compared with Western religions, Buddhism and Jainism do not embody a clear human centralism position in terms of doctrine, and Taoism also holds a kind of gentle bio-egalitarianism. With modern science development, no matter the human centralism animal ethics in Western religions, or the biological egalitarian animal ethics in Eastern religions, there are some conflicts and fusions on theoretical and practical aspects. Through the comparative study of Eastern and Western religions in animal ethics, we can clarify the differences and integration of animal ethics in the Eastern and Western religious systems, and actively seek the coexistence and development of modern science and technology and religious animal ethics in theory and practice, which has a very important positive value in promoting the harmonious development of human and nature and improving the ecological environment.
\end{abstract}

Keywords: Animal Ethic, Humanism, Biological Egalitarianism

\section{Introduction}

Animals are regarded as man's most important friends, especially in religious thought. Some animals are even endowed with the meaning of God, who plays a very important role in man's life. Since ancient times, Eastern and Western religions have different ideological origins and values, in which the animal ethics embodies different theoretical positions and contents. The purpose of this paper is to clarify the differences and fusion of animal ethics in the Eastern and Western religious systems through the comparative study of animal ethics in Eastern and Western religions. And it also aims to seek the theoretical and practical coexistence and development of the religious animal ethics and modern science and technology.

\section{Western Religion and Humanitarianism Animal Ethics}

The foremost dominant religion of Western society regarded Abraham as their common ancestor. In the course of historical development, three most influential religions have been formed, namely Judaism based on the Old Testament, Christianity based on the New Testament, and Islam based on the Koran. The three religions originated from the same source, but for the classical enlightenment and the Prophet's endorsement, there is a change in inheriting and innovating.

In the context of human-animal relations, the ancient Jewish tradition favored the idea of the subordination of animals to humans, but also stressed the need to minimize the suffering caused by the consumption and use of animals. This concern is reflected not only in the doctrine of diet and slaughter, but also in the condemnation of hunting and cruelty to animals for entertainment, such as bullfighting. In Deuteronomy, there are rules for the protection of animals, such as the famous injunction that "when an ox treads the corn, it must not be gagged" (Deuteronomy 25: 4) The most important Sabbath in Judaism is a day of rest not only for humans but also for livestock, and the Sabbath is an opportunity for animals to eat freely. Moreover, in Judaism, 
animal sacrifice is not required by Jehovah and is therefore useless (Jeremiah 6: 20 7: 21). If the people do not obey, and their hands are stained with blood, then in Jehovah's eyes their sacrifice and fasting are nothing but crimes [1]. Therefore, in the Jewish Oracle, the attitude to animal sacrifice is always indifferent or even against, which reflects the ancient Judaism's love and charity for animals.

Christianity is the most mainstream revealed religion in the Western world at present. There are many doctrines on the relationship between man and animal, which has been studied in a more concentrated and in-depth field in the field of animal and religion at present. The Bible states, "God blessed Noah and his sons, and said unto them, be fruitful and multiply, and fill the earth, and all the beasts of the earth, and all the birds of the air, shall be afraid of you, and shall give into your hands all the insects of the earth, and all the fishes of the sea; and every living creature shall be your food, and I will give it to you as a vegetable" (Genesis 9: 1-3). The theology of the Middle Ages was influenced by Aristotle's natural teleology. Tomas Aquinas declared that man is the most perfect being among all the natural things. God offers grace to man for his own sake, and to other beings only for the sake of man, so that man may use plants and treat animals as he pleases. Since then, majority Christians generally accepted and agreed with the idea. Although the Bible also contains such contents as "the righteous man takes care of the lives of his livestock", which requires people to care about animals and other beings, the reason is that cruelty to animals encourages cruelty to others, and so its root is still concern for human beings.

Within current Western Christendom, however, Andrew Linzey who is an English Anglican priest, theologian, and prominent figure in Christian vegetarianism was dissatisfied with traditional Christian attitudes toward animals, and actively sought theology sources of the ideas about the status of animals and the relationship between humans and animals. And opened a new chapter of Animal Theology with Christianity and the Rights of Animals. He believed that God's Love was not only for human beings but for all living beings (including animals), Christians must open a new and broad mind to accommodate the two Great Gospel Truths: First, animals are the creatures created by God, who are neither the property of mankind, nor the sharing of facilities, resources, or goods, but are precious creatures in the sight of God [2]; Second, animals are suffering like Christ [2]. In Linzey's view, Christians should recognize the basic moral status of animals and the animal rights is in the Gospel of truth endowed by God when he created the world.

The Islamic tradition holds that human beings are the most important and that animals exist for human use only. The Koran says, "All ye people, eat all the lawful and good food of the Earth" "He forbids you to eat only the dead, blood, pork, and animals that are not slaughtered in the name of Allah." [3] According to Islamic eating customs, people are allowed to eat animals excluding pigs, but only if the name of Allah is spoken at the time of slaughter. While advocating the practical status of animals, Islam also emphasizes the importance of animals. Many of the Koran chapters are named after cattle, bees, spiders, ants and other animals. It also emphasizes that God created animals for the benefit of mankind and that cruelty to animals is prohibited. The Koran records that the privileged class of the Thamud usurped water plants and pastures, and that the envoy Saleh exhorted them to respect the rights of the animals, while the Thamud denied the rights of the animals and tore their tendons. So Allah destroyed the Thamud. For the Islam that "there is no God but God", the Prophet Muhammad's Maxim “whoever treats God's creation well, treats himself well" has become the belief foundation and the moral behavior standard for the believers to treat animals well.

Above all, the Abrahamic religions (Judaism, Christianity and Islam) all embody a kind of religious humanitarianism in the relationship between man and animal. They all affirm that man has higher intrinsic value. Although animals should be treated with compassion, they are still subordinate. Therefore, in a sense, this kind of animal ethics can be regarded as the human centralism in the Religious field. The difference between the human centralism in philosophy and in religion is that the reason and criterion for the higher intrinsic value of human beings in the field of religion does not depend on the individual choice of human beings, nor on the collective agreement. It is based on some external source of supernatural moral standards, that is, the will of God, and therefore has transcendentalism. Of course, in the Abrahamic series, the doctrines reflect both God's love for mankind and his divine compassion for animals. The reason for this is that the religious experience comes from the human social experience and the natural experience, that is, the religious experience comes not only from the human experience, but also from the interaction of the whole natural world, from the experience of human interaction with animals, and even the experience of animals themselves. Of course, the so-called animal experience is also from the human experience, written and narrative by people [4]. As a result of the close connection and interaction among the various factors producing the religious experience, a cognitive and practical picture of the three-tier god-man-animal order in the religious world has emerged.

\section{Eastern Religions and Biological Equilibrium's Animal Ethics}

Eastern religions have doctrines and principles that differ markedly from those of the Western in their treatment of animals, notably Buddhism and Jainism, which originated in India. Taoism which originated in China, also to some extent represents the gentle biological equilibrium attitude of the Eastern.

Buddhism advocates mercy and equality of all living beings. The main idea of treating animals is to oppose all acts of killing. According to Maha Prajnaparamita Sastra, "compassion is the root of Buddhism", "Great compassion delights all living beings and pulls out all living beings' suffering." It is obvious that the object of Buddhist compassion is not limited to human beings, but all life 
including other non-human animals, that is, the so-called "all living beings have buddhist nature". On the one hand, all life is the same Tathāgata body, which illustrates the equality of all living beings from the perspective of the origin of life. On the other hand, all subjects of life can cultivate Buddha, which shows the equality of life from the turn of life. On the basis of affirming the equality of all living things, the care of animals in Buddhism is embodied in the spirit of compassion for the interests of animals in the concrete life, the most important and direct embodiment of which is the proposition of vegetarian diet. In particular, Buddhism not only advocates a vegetarian diet in normal times, but also explicitly opposes the use of animal medicines to save human lives. Master lian-chi, an Eminent Monks of the Ming Dynasty, made it clear “A man mustn't kill to feed his own stomach. It is better to be innocent than to lose a thing's life and give a whole person's name. I do not know that the noble man is inferior to the animal, but common sense is, instead of the equal hearts of all Buddhas and bodhisattvas. Kill a life, live a life, benevolence is not for, and the situation of the division of death and life, not necessarily its ability to live. It will only increase injustice. Those who are ill think it over, and those who practice also think it over." [5] In other words, even if killing animals can save people's lives, it is not a benevolent act, not to mention killing animals can not necessarily save people's lives.

India's indigenous Jainism has stricter, even harsher, attitudes toward animals. The essential content of its doctrine is not only "right knowledge", "right view", but the most important is "right action", that is, "Ahimsa" as the first of all precepts. Orthodox Jains cannot light a lamp in the dark because it may kill moths or hold a fire because it may kill insects; they filter water before boiling it and cover the nose and mouth with gauze to avoid inhaling or ingesting insects; use a soft broom to carefully sweep the ground before you walk; don't shave your head or body hair (pull it by the roots instead) to avoid cutting off lice; never wade through water to avoid stepping on bugs. Abstaining from killing causes Jains to avoid all life-threatening crafts altogether, such as fire and sharp instruments, muddy water, and most industrial jobs. As for agriculture, especially farming, of course, is completely impossible, because it always hurts the insects in the soil [6].

Taoism, as a native-born religion in China, taking Tao as its root, fairies as its belief, and holds the concept of the unity of all things. It extends the value of life to all things in the world, but not only to animals and plants. "All corporeal things contain Taoist nature", "all things in heaven and earth are of the same kind with me, and there is no nobility or inferiority in them" etc. All of these papers show the idea of species equality. It is also on the basis of this idea, Taoism put forward the "respect Tao and life" requirements, a clear request to love all animals as people. In other words, the belief that everything in the universe is one lays the metaphysical foundation of Taoist animal ethics. There are many books and records reflecting the Taoist thought of killing and protecting students, taking the example of a Taoism early precept "Laojun says one hundred and eighty commandments", in which it is clearly required that "one must not trample domestic animal" "one must not exhaust water" and "one must not fish, hunt or kill all living beings". "Do not go up the tree and explore the nest break eggs", "do not cage birds and animals", "do not frighten birds and animals", "birds, fish and other animals that are killed by people are not allowed to eat" [7].

Compared with Western religions, Buddhism and Jainism do not embody a clear human centralism position in terms of doctrine, and Taoism also holds a kind of gentle bio-egalitarianism. They treat human beings as being of equal value to other species and require loving treatment of natural beings, including animals. In Buddhism, Jainism and Taoism, all beings are closely related, and the well-being benefits all sentient and inanimate beings, in which animals enjoy equal moral status with human beings. This embodies the core value of the eastern traditional religious view of the universe: The harmony of the whole universe, that is, the natural order, is the greatest good. At this level, we can see the strong inclusiveness of the concept of equality in traditional Eastern religions, whose concern go far beyond individuals or groups of a certain class. It also includes animals, plants and other natural forms such as mountains and rivers. At the same time, the traditional "ahimsa" thought in the ancient Eastern religion also provided source for the later Nonviolence ethics theory.

However, despite the warmth and goodwill of the Buddhist slogans of "compassion" and "equality of all beings", the reincarnation theory still shows that the status of animals is actually lower than that of human beings, not the true "equality of all beings". On the surface, people can be reincarnated as animals and animals can also be reincarnated as people, reflecting the "equality of all living beings". However, in terms of the specific ways of its transformation, two points are worth noting: first, if animals have good Karma, they can be reincarnated into human, and if people have evil Karma, they will be reincarnated into animal, which shows that humans still higher than animals; Second, there are also differences in animals. Some animals have a higher moral status than others, which is reflected in the fact that people who repay small evil may be reincarnated as high-ranking and noble animals, such as Lions and Tigers while a person with a greater sense of evil may be reincarnated as a lower and more evil animal [4]. Thus, Buddhism does not break out of the human centralism as a means of doctrinal control.

Furthermore, from the perspective of Teleology, the moderate bio-egalitarianism religious thought cannot get rid of the limitation of human centralism stand in essence. The mysterious "indiscrimination of love" is not so much the divine power given by nature to conquer the soul, but rather a necessary way to the other world. The key to indiscrimination of love, or altruism, lies in the fact that salvation for oneself is a confirmation of biological equality, not in the discomfort that comes from the plight of animals. In short, the ultimate goal of non-violence, which is based on the egoism thought of self-liberation, is only for personal "salvation", and the respect 
of Tao is only for personal "becoming immortal". Thus, on both levels, the inherent stance of the Eastern religions towards animals remains human centralism. It is only less visible and more mysterious than the more pronounced human centralism tendency in Western religions.

In a word, the missionary work of "all beings are equal" has covered the spread of the traditional Eastern religion with a coat of both magnificence and simplicity, so that it has been converted by the majority of believers and the religious power has been strengthened. Moreover, the essence of its thought of "respecting life and caring for animals" enriches the traditional oriental culture in a certain sense, and is also of great significance to modern social life.

\section{Conflict and Fusion -- Traditional Religious Animal Ethics and Modern Scientific Development}

With the development of the Western Renaissance and Protestant Reformation, the influence of the church monopoly on the history of Western thought has gradually declined, and the consciousness of the Eastern traditional religion has also gradually weakened in the process of modernization. The growth of global modern scientific ideas and the development of science and Technology provide a new theoretical direction and practical support for the relationship between man and animals. The early religious traditional view of animals began to conflict with the use of animals in science both theoretically and practically. With the development of modern biology, the belief foundation of the traditional religious animal view has also been challenged to a certain extent.

On the one hand, in the religious tradition of the Middle Ages, people did not have an objective relationship with animals in the sense of modern science, and did not pursue the goal of objective cognition and didn't study animals by means of calculation, measurement and experiment. The "ahimsa" religious ideas of that time can be widely recognized and disseminated. However, the development of modern science, especially the development of biological science, is based on the use of animals. If we do not take non-human animals as the objective research object, the development of science will be difficult. Therefore, in the traditional Eastern religion, the doctrine of "abstaining from killing" puts religion and modern science in the conflict and predicament of theory.

On the other hand, the Abrahamic religious system recognizes that man can use animals, which is consistent with the idea of using animals in modern science. In both the Old Testament and the New Testament, God created the universe primarily for the benefit of mankind. In an age of rapid scientific development, humans have found a religious justification for sacrificing animal welfare for human development, but at the cost of unchecked exploitation. Thus, many wild animals are endangered and the balance of species is disturbed. The natural environment deteriorates rapidly and the ecological crisis starts to spread in the global scope. A kind of difficulty and contradiction about the practical level of animal utilization is staged between religion and modern science.

The requirement of animal welfare in Eastern and Western religions comes from the will of God on the one hand and the cognition of animals in religious experience on the other hand. Both the Abrahamic religions, which are concerned with the value of animals, and the eastern religions, which emphasize the equality of all living beings, agree to a certain extent that animals have cognitive and sensory abilities which are similar to human beings. In particular, the eastern religions which hold the attitude of bio-egalitarianism take this as the basis of their belief. However, as early as 1969, scientists conducted an in-depth study of one of the most intelligent species of animals, the dolphin, and the results showed that dolphins do not have similar cognitive, conscious and communication skills to humans [8]. This view is widely accepted in the biological community. Even though animal experiments in recent years have shown that some animal behavior is conscious and rational, the idea that there is a fundamental and insurmountable gap between animal intelligence and human intelligence is still widely accepted. Therefore, from the biological level, modern science has broken the foundation of religious bio-egalitarian belief, and once led traditional religion and modern science into a tense confrontation situation.

Despite the inevitable conflicts between traditional religions and modern science in many aspects of theory and practice, it is in the conflict between religion and science that many questions is gradually clarified like, the relationship between man and animals, what the position of man and animals is, whether animals have rights and how people should treat animals. Western traditional religion and modern science have reached the same conclusion from different theoretical sources, that is, whether it is the revelation and arrangement of religious transcendental God, or the result of natural selection from the perspective of science, man can use animals, but they should use them mercifully [9]. Therefore, on the realistic level, the human centralism of the Western Abrahamic religion system can be more integrated with the production and life practice of modern society than the gentle bio-egalitarianism of the traditional eastern religions.

Although the tradition of "ahimsa" in ancient eastern religions has been shelved by modern science, modern science does not exclude the role that such religious beliefs play in maintaining the balance of nature and harmonious development between man and nature. Spiritual Purity is considered nobler than scrupulous observance of the law, and all mysticism, whether Christian or Buddhist, have one thing in common: they value the state of mind. They think that the right behavior must come out of this. The value of faith lies not in itself, but in its ability to guide people's life behavior. Positive religious cultivation can make people have a good moral sense. In this sense, in the scientific prosperous modern society, the internalized religion belief of "loving animal" still has a very significant positive effect on the harmonious development of man and animals as well as 
man and nature.

\section{Conclusions}

From the perspective of religion, philosophy and science, the animal world is a part of the natural world, interacting with the human world to shape the natural world and create the current state of the human outlook. Although modern science is constantly pushing the innovation and transformation of animal ethics, the religious animal ethics still exists and develops to a certain extent. As a social phenomenon and order, all kinds of religions also play their roles in different fields of life, especially in the ecological field of the relationship between man and nature. And after a long period of adaptation and adjustment to modern science and philosophy, its positive value in promoting the improvement of the ecological environment becomes more and more obvious, As Mile Durkheim said "there is something timeless about religion that is destined to outlast than the particular religious symbol that all religious ideas have sequentially adopted as their shells." [10]

\section{Fund Project}

National Social Science Fund of 2017: Research on ethical dilemma and Countermeasures of animal utilization in traditional Chinese medicine industry (Project No.: 17bzx101); Jiangsu Social Science Fund of 2015: Research on ethical dilemma and Countermeasures of animal medical application (Project No.: 15zxc004)

\section{References}

[1] Marx Weber, Ancient Judaism, Guangxi Normal University Press, 2010, p363.

[2] Andrew Linzey, Christianity and Rights of Animals, London: SPCK, 1987, pp. 68-69, pp. 94-98.

[3] Li Anhui, The Concept of Islamic Cultural Economy in China and its Contemporary Significance, Hui Studies, (2), 2012.

[4] Chen Huaiyu, Animals and the Political and Religious Order of the Middle Ages, Shanghai Ancient Books Publishing House, 2012, p5, p9.

[5] Mang Ping, The World of Things and Me-Chinese Belief, Life and Animal View, China University of Political Science and Law Press, 2009, p103.

[6] Max Weber, Religion in India: Hinduism and Buddhism, Guangxi Normal University Press, 2010, p270.

[7] Qiang Yu, The Law Spirit of Laojun's 180 Commandments, Chinese Taoism, (6), 2000.

[8] Paul W. Taylor, The Ethics of Respect for Nature, in David Schmidtz and Elizabeth Willott (ed.) Environmental Ethics: What really Matters, What really Works. Oxford: Oxford University Press, 2002, pp. 83-84.

[9] Peter Singer, Animal Rights and Human Obligations, Beijing: Peking University Press, 2010, pp. 129-131.

[10] Emile Durkheim: Fundamental Forms of Religious Life, Business Press, 2013, p589. 